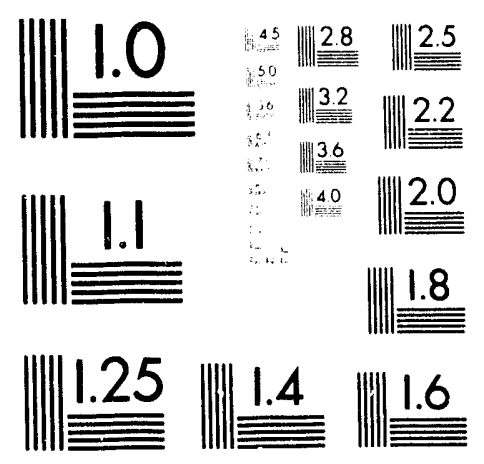



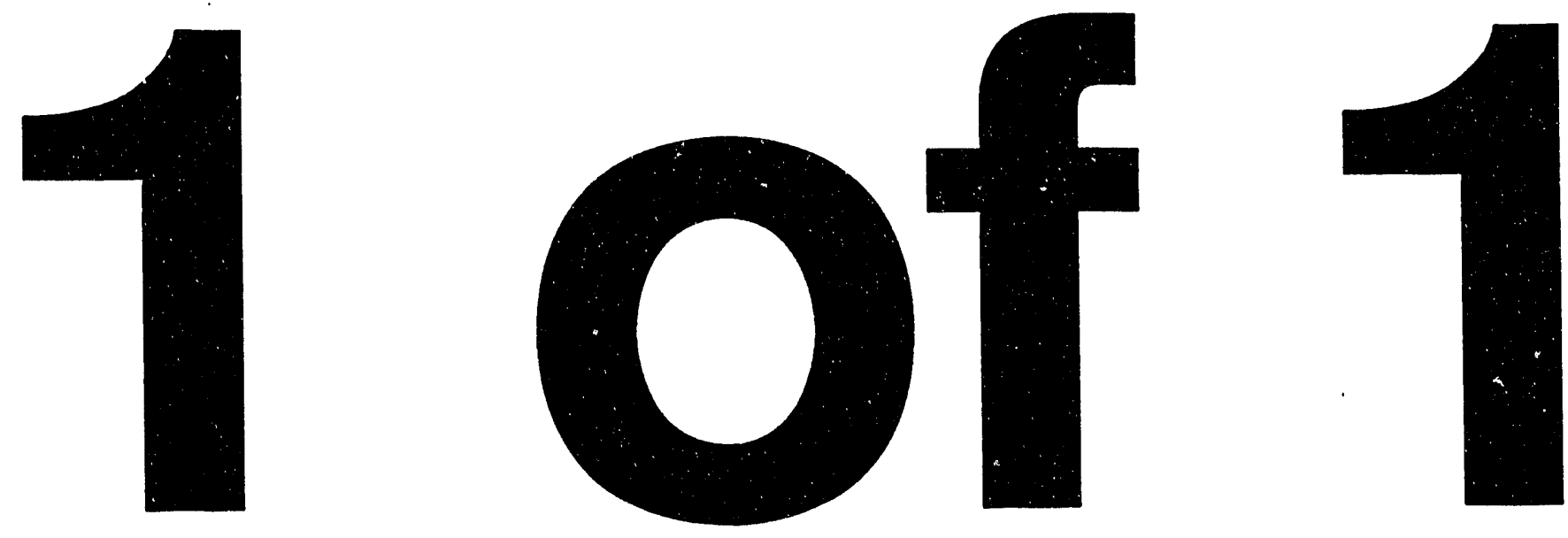


\title{
Operational Modes and Control Philosophy of the SSCL Magnet Test Lab. (MTL) Cryogenic System*
}

\section{RFCEIVED \\ SEP 231993 \\ OSTI}

\author{
V. Ganni, R. Than, and M. Thirumaleshwar \\ Superconducting Super Collider Laboratory ${ }^{\dagger}$ \\ 2550 Beckleymeade Ave. \\ Dallas, TX 75237
}

May 1993

*Presented at the Fourth Annual International Symposium on the Super Collider, March 4-6, 1992, New Orleans, Louisiana.

${ }^{+}$Operated by the Universities Research Association, Inc., for the U.S. Department of Energy under Contract No. DE-AC35-89ER40486. 
OPERATIONAL MODES AND CONTROL PHILOSOPHY OF THE SSCL MAGNET TEST LAB. (MTL) CRYOGENIC SYSTEM

\author{
V. Ganni, R. Than, M. Thirumaleshwar* \\ Superconducting Super Collider Laboratory ${ }^{\dagger}$ \\ 2550 Beckleymeade \\ Dallas, TX 75237, USA
}

\title{
INTRODUCTION
}

The MTL's function is to test prototype and industrially manufactured magnets for the Superconducting Super Collider Laboratory (SSCL). The cryogenic system of the MTL has a main refrigeration system consisting of a two-stage compression system, a refrigerator/liquefier coldbox, a liquid helium dewar, warm gas storage, and a regeneration skid. The MTL cryogenic system also includes the following auxiliary equipment: two cleaning, cooling, warmup and purification (CCWP) coldbox modules with a regeneration skid for the charcoal beds, two CCWP compressors, a dehydration skid with its own regeneration system, a pump box, a refrigeration recovery unit, and five distribution boxes. Figure 1 describes the general flow of these systems. At any given time, the refrigeration system has the capacity to simultaneously test at least six magnets under normally required testing conditions.

Every magnet will undergo cleaning, cooldown, and filling prior to general testing, conditioning, quench testing, and other experiments. At the completion of general testing, etc., the magnet must be emptied prior to warming it up to ambient temperature. Furthermore, conditioning, training, and testing of the magnets can be carried out at different temperatures between $4.5 \mathrm{~K}$ and $2.5 \mathrm{~K}$. The cryogenic system is desigı:ed to test multiple magnets, not all of which are necessarily in the same preparational or operational stage. This paper describes the different operational modes and the behavior and control of the total cryogenic system during multiple magnet tests.

\section{EQUIPMENT DESCRIPTION}

The refrigerator/liquefier system has two $185 \mathrm{~kW}(250 \mathrm{HP})$ first-stage and two $525 \mathrm{~kW}$ ( $700 \mathrm{HP}$ ) second-stage compressors. The $4 \mathrm{~K}$ refrigeration is accomplished using liquid nitrogen precooling and work extraction by four expanders. The system has a design capacity of $2100 \mathrm{~W}$ and $21 \mathrm{~g} / \mathrm{s}$ at $4.4 \mathrm{~K}$. A 40,000 liter helium dewar serves as the liquid storage and energy manager. The design and basic operation of the refrigerator and its response to varying load conditions has already been explained in a previous paper. ${ }^{1}$

The refrigeration recovery system, shown in Figure 2, has a two-pressure-level vacuum system that provides the vacuum to subcool the supply helium to the magnet. This system has two $110 \mathrm{~kW}$ ( $145 \mathrm{HP}$ ) vacuum pump trains. A refrigeration recovery heat exchanger module with two Joule-Thompson valves recovers the cooling capacity of the boil-off flow from the subcoolers by cooling high pressure flow and supplying the resulting two-phase helium to the dewar. The two-pressure-level vacuum system allows for efficient, flexible, and stable testing of multiple magnets over the required temperature range of $4.5 \mathrm{~K}$ to $2.5 \mathrm{~K}$.

The pump box, shown in Figure 2, contains a make-up pump and two circulation pumps. The make-up pump has a capacity in excess of $200 \mathrm{~g} / \mathrm{s}$ and the two circulation pumps can provide a circulation rate in excess of $500 \mathrm{~g} / \mathrm{s}$ of helium flow to the supply header. Two surge vessels in the pump box attenuate pressure pulses generated in the system.

The CCWP system's function is to clean, cool down, and warm up a magnet test stand and purify the helium gas. This system, shown in Figure 3, has its own compressors, oil removal skid, and regeneratiun skid. It also has a dehydration skid for moisture removal and an $80 \mathrm{~K}$ charcoal bed to remove impurities from the helium. The return pressure is maintained at 2 bar and the supply pressure to the magnet test stand can be

\footnotetext{
* Guest collaborator from Center for Advanced Technology, Indore, India.

+ Operated by the Universities Research Association, Inc., for the U.S. Department of Energy under Contract No. DE-AC35-89ER40486.
} 


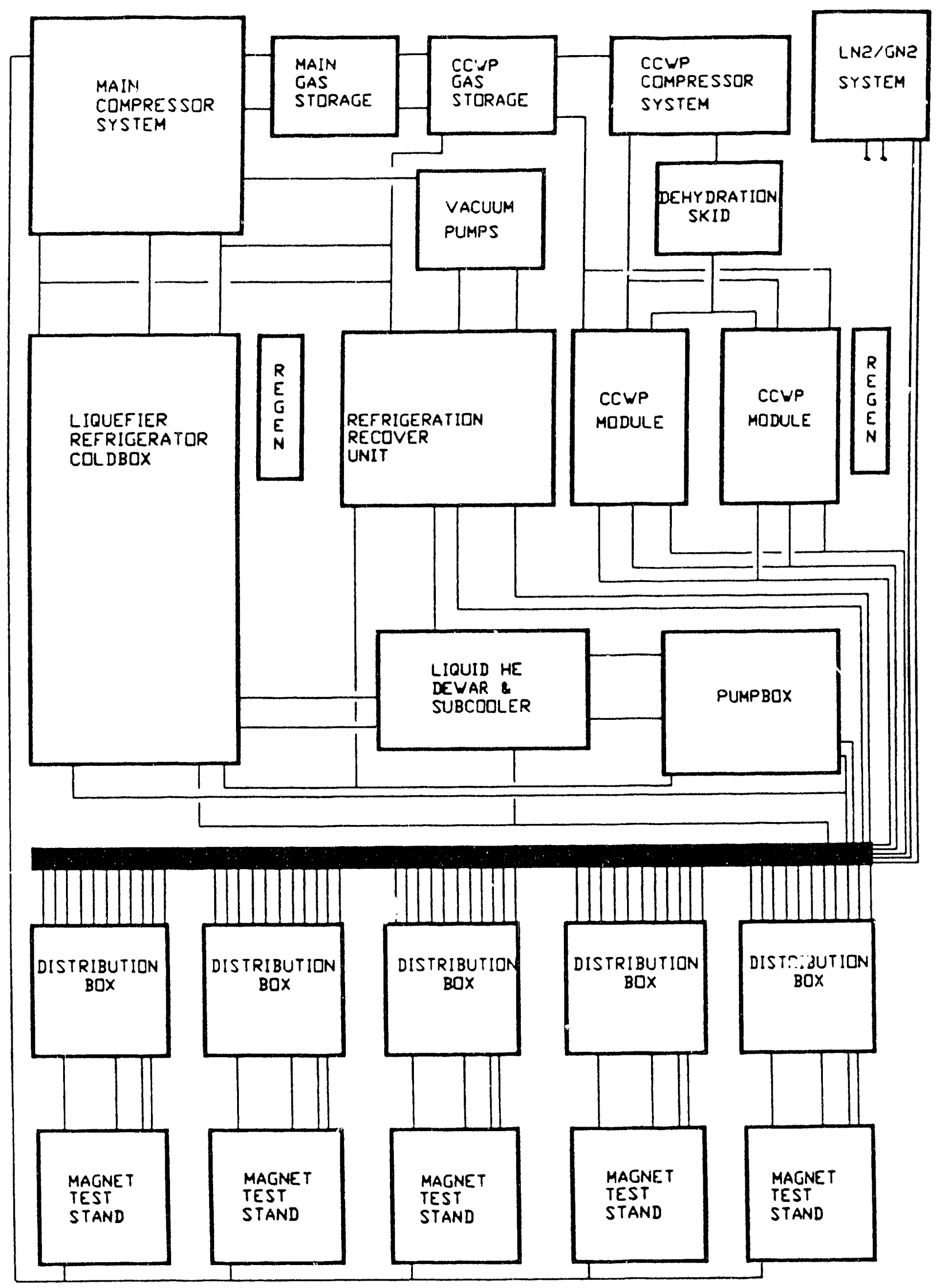

FIGURE 1. MTL CRYOGENIC SYSTEM BLOCK DLAGRAM 
as high as 6 bar. The CᄃWP system has two $95 \mathrm{~kW}$ (125 HP) compressors. Refrigeration for the CCWP flow is provided by liquid nitrogen.

The distribution box, as shown in Figure 2, serves as the valve hox between the magnet test stand and the other equipment (refrigerator, pump box, refrigeration recovery and the CCWP units). It also contains heat exchangers for subcooling the flow of supply helium to the desired temperature. The subcooler bath temperature is maintained by the refrigeration recovery system connected to the phase separator. The distribution boxes are nitrogen heat shielded. There are separate supply and retum lines with control valves on each distribution box for each of the following flows:

- Warm helium gas supply from CCWP

- Cold helium gas supply from CCWP

- Return helium line to CCWP

- Liquid helium supply from pump box

- Liquid helium return to pump box

- Quench return line
- Vacuurn 1 from phase separator (for $2.5 \mathrm{~K}$ )

- Vacuum 2 from phase separator (for $3.6 \mathrm{~K}$ )

- Gaseous nitrogen supply

- Liquid nitrogen supply

- Nitrogen vent line

The magnet test stand cryogenic system, shown in Figure 2, consists of a feed can, the magnet, and an end can. These three components are treated as a unit for all operating conditions. The feed can is connected to the distribution box through $U$ tubes. A magnet change does not require warmup of any subsystems upstream of the $U$ tubes.

\section{CLEANING OF A MAGNET TEST STAND}

The magnet is cleaned by circulating clean warm helium gas through the magnet test stand from the CCWP unit. The CCWP system return pressure is controlled at 2 bar and the supply pressure can be as high as 6 bar. In the CCWP coldbox, the high pressure helium is cooled to $80 \mathrm{~K}$ with the aid of liquid nitrogen. The helium gas exits the second heat exchanger (nitrogen boiler) and enters the charcoal adsorber. A portion of the $80 \mathrm{~K}$ clean gas may be sent to the test stands for cooldown purposes while the remainder of this gas is warmed back to room temperature by exchanging energy with the incoming flow from the compressors. This clean warm gas is sent through the warm supply header to the distribution box(es) and on to the magnet test stand(s). The impure exit gas containing moisture and air from the test stand is returned through the CCWP return header and back to the CCWP module. This impure gas is passed through the dehydration skid for moisture removal before it is returned to the CCWP compressors. The nominal flow through the magnet system for cleaning is about $15 \mathrm{~g} / \mathrm{s}$. The flow rate to the magnet is controlled by a flow control valve in the distribution box on the warm supply line. The return gas is sampled for moisture content. The cleanup continues until in the return helium reaches the required moisture level.

\section{COOLDOWN AND FILLING OF A MAGNET TEST STAND}

Cooldown and fil!ing of the magnet test stand occurs in three phases. Cooling from $300 \mathrm{~K}$ to $80 \mathrm{~K}$ is accomplished with the CCWP unit, using nitrogen as the refrigerant. Below $80 \mathrm{~K}$, cooling and filling are accomplished with liquid helium supplied from the refrigerator/pump box.

The first phase of cooldown, from $300 \mathrm{~K}$ to $80 \mathrm{~K}(\sim 90$ percent of cooldown load), is achieved using high pressure gas from the CCWP compressors which has been cooled to $80 \mathrm{~K}$ by the nitrogen pre-cooling loop in the CCWP coldbox. The helium gas exits the pre-cooling loop heat exchangers and enters the carbon adsorber. If no cooldown ramp is required for the magnet (to reduce the thermal stress), the $80 \mathrm{~K}$ gas is sent through the CCWP cold supply header to the distribution box(es) and on to the magnet test stand(s). If a temperature ramp is required for the cooldown, clean warm helium is mixed with cold helium in the distribution box to generate gas at any required temperature between $300 \mathrm{~K}$ and $80 \mathrm{~K}$. The appropriate supply temperature is automatically obtained by controlling cold and warm supply flows with a feedback signal from the load supply gas temperature. The gas from the magnet is returned through the CCWP return header to the CCWP module. Based on its retum temperature, the gas either bypasses the heat exchanger or returns through the appropriate section of the heat exchanger to recover refrigeration. The gas is finally returned to the compressors after warmup and moisture removal by the dehydration skid.

The second phase of cooldown, from $80 \mathrm{~K}$ to $12 \mathrm{~K}$, is accomplished by supplying $4.5 \mathrm{~K}$ hium at 4 bar from the refrigerator/pump box to the test stand via the distribution box. A flow control valve located downstream of the subcooler in the distribution box maintains a flow rate of $20 \mathrm{~g} / \mathrm{s}$ to the magnet test stand. The helium from the test stand is retumed through the quench return header (by resetting the quench return/cooldown valve control to $2.5-3$ bar) to the refrigerator where it is selectively admitted to the proper heat exchanger depending upon the helium's temperature.

The third phase of cooldown starts when the return helium temperature drops below $12 \mathrm{~K}$. At this temperature, the return flow in the quench header is diverted to the dewar. As the magnet test stand is further cooled and filled, the supply flow rate is ramped from $20 \mathrm{~g} / \mathrm{s}$ to the required circuiation rate. The normal circulation loop can be estahlished when the magnet return temperature has reached $5 \mathrm{~K}$ by opening the return 


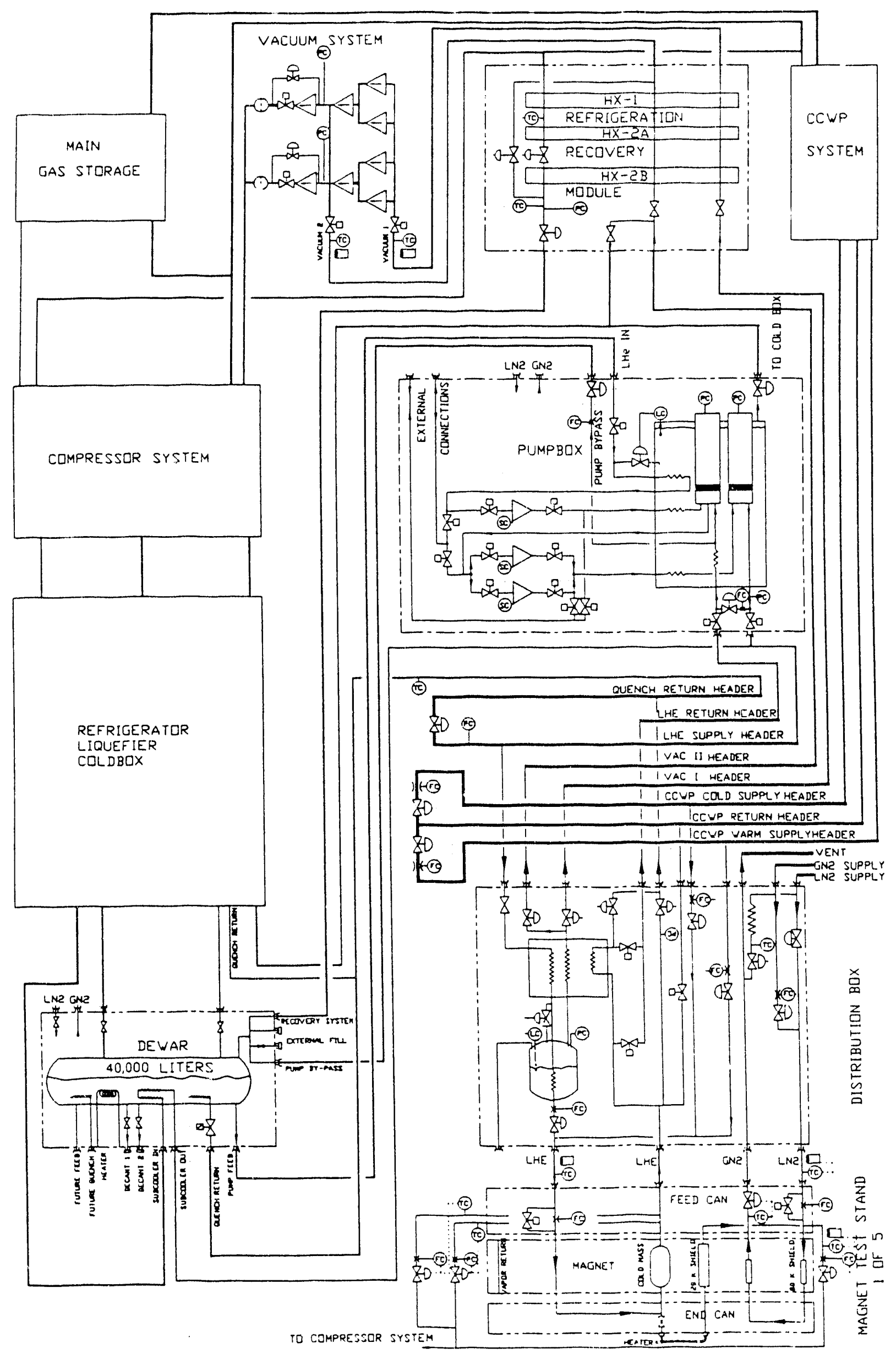


heat exchanger by pass valve to the liquid return line (pump box suction header) and by resetting the quench return valve to its normal control pressure of 4.5 bar. For lower temperattre operation, the bypass valve is closed and the flow is returned through the heat exchanger. The time required for each phase of cooldown and wart:up is calculated by computer simulation and is given in Table 1 . The duration of these transient processes will be longer if control of the temperature gradient in the magnet is required.

Table i. Magnet test modes

\begin{tabular}{|c|c|c|c|c|c|c|c|}
\hline Mode & System & $P$ inlet & $T$ inlet & Flow & Return Temp. & Duration & Remarks \\
\hline Clean & CCWP & 3 bar & $300 \mathrm{~K}$ & $15 \mathrm{~g} / \mathrm{s}$ & N/A & $\begin{array}{l}\text { Depends on } \\
\text { moisture }\end{array}$ & $\begin{array}{l}\text { Stop on low dewpoint } \\
\text { indication }\end{array}$ \\
\hline Cool & CCWP & $6-3 \mathrm{bar}$ & $\begin{array}{l}300 \mathrm{~K}- \\
80 \mathrm{~K}\end{array}$ & $80 \mathrm{~g} / \mathrm{s}$ & $300 \mathrm{~K}-80 \mathrm{~K}$ & 5 hrs & $\begin{array}{l}80 \mathrm{~K} \text { supply, or }>5 \mathrm{hrs} \\
\text { for programmed } \\
\text { cooldown }\end{array}$ \\
\hline Cool & Main & 4 bar & $4.5 \mathrm{~K}$ & $20 \mathrm{~g} / \mathrm{s}$ & $80 \mathrm{~K}-12 \mathrm{~K}$ & $2 \mathrm{hrs}$ & Recover in main coldbox \\
\hline Cool & Main & 4 bar & $4.5 \mathrm{~K}$ & $20-100 \mathrm{~g} / \mathrm{s}$ & $12 \mathrm{~K}-4.5 \mathrm{~K}$ & $0.5 \mathrm{hr}$ & $\begin{array}{l}\text { Cool and fill, send rerurn } \\
\text { flow to dewar }\end{array}$ \\
\hline Test & Main & $\begin{array}{l}4 \text { bar } \\
4 \text { bar }\end{array}$ & $\begin{array}{l}4.5 \mathrm{~K}-3.6 \mathrm{~K} \\
3.6 \mathrm{~K}-2.5 \mathrm{~K} \\
\end{array}$ & $\begin{array}{l}100 \mathrm{~g} / \mathrm{s}^{*} \\
50 \mathrm{~g} / \mathrm{s}^{*}\end{array}$ & $\begin{array}{l}4.6 \mathrm{~K}-3.8 \mathrm{~K} \\
3.9 \mathrm{~K}-2.9 \mathrm{~K}\end{array}$ & & $\begin{array}{l}\text { *Nominal flow rates for } \\
\text { these temperature ranges }\end{array}$ \\
\hline Warm & $\begin{array}{c}\text { CCWP \& } \\
\text { Main }\end{array}$ & 4 bar & $80 \mathrm{~K}$ & $20 \mathrm{~g} / \mathrm{s}$ & $4.5 \mathrm{~K}-12 \mathrm{~K}$ & $0.5 \mathrm{hr}$ & $\begin{array}{l}\text { Empty inventory into } \\
\text { dewar }\end{array}$ \\
\hline Warm & $\begin{array}{c}\text { CCWP \& } \\
\text { Main }\end{array}$ & 4 bar & $80 \mathrm{~K}$ & $20 \mathrm{~g} / \mathrm{s}$ & $12 \mathrm{~K}-60 \mathrm{~K}$ & 3 hrs & $\begin{array}{l}\text { Recovery in main } \\
\text { coldbox }\end{array}$ \\
\hline Warm & CCWP & $6-3$ bar & $300 \mathrm{~K}$ & $50 \mathrm{~g} / \mathrm{s}$ & $60 \mathrm{~K}-300 \mathrm{~K}$ & $10 \mathrm{hrs}$ & $\begin{array}{l}\text { Recover in CCWP } \\
\text { coldhox }\end{array}$ \\
\hline
\end{tabular}

\section{NORMAL OPERATION OF A MAGNET TEST STAND}

A pair of circulation pumps in the pump box maintains the circulation through the distribution boxes and the magnet test stands. The distribution box can deliver 4 bar subcooled helium between $2.5 \mathrm{~K}$ and $4.5 \mathrm{~K}$ to the magnet test stand with the aid of the refrigeration recovery vacuum system. The normal cooling loop is established once the magnet test stand is cooled and filled. The circulation pumps provide the 4 bar subcooled helium flow for maintaining the magnet temperature during normal testing. The booster pump in the pump box draws liquid from the dewar at a nominal pressure of 1.2 bar and supplies this to the circulation pumps at approximately 3.5 bar. The supply to the circulation pumps comes from the test stand return and makeup flows. The circulation pumps have the capacity to provide flow rate in excess of $500 \mathrm{~g} / \mathrm{s}$ and at a pressure of 4 bar. This flow is subcooled before leaving the pump box. The supply flow enters the distribution box and is precooled through a heat exchanger by the flow returning from the magnet. However, if this returning flow is above $4 \mathrm{~K}$, then it bypasses the heat exchanger. The supply flow is further cooled in the subcooler and a flow control valve located downstream of the subcooler resulates the flow to the magnet test stand. Part of the supply flow from the pump box is flashed into the subcooler bath to provide cooling to the subcooler flow. Two vacuum pressure lines are connected to the subcooler phase separator. Vacl provides a maximum vacuum corresponding to a saturation temperature of $2.4 \mathrm{~K}$. and $\mathrm{Vac} 2$ produces a saturation temperature of $3.5 \mathrm{~K}$. The helium supply temperature is indirectly controlled by the subcooler phase separator vacuum valves on the vacuum lines in the distribution box that maintain the required vapor pressure.

\section{WARMUP OF A MAGNET TEST STAND}

The magnet test stand is warmed up in three phases. The first phase empties the cold helium ( $4 \mathrm{~K}$ ) into the dewar. This is accomplished by supplying up to $50 \mathrm{~g} / \mathrm{s}$ of $80 \mathrm{~K}$ helium from the CCWP unit to the test stand with the return flow being directed into the quench header by resetting the quench/cooldown valve control to 2.5-3 bar. The return flow is directed into the dewar so long as the temperature is below $12 \mathrm{~K}$. When the return flow reaches $12 \mathrm{~K}$, the second phase of warmup be gins. The CCWP flow is limited to $20 \mathrm{~g} / \mathrm{s}$ and the magnet return flow is directed to the refrigerator coldbcix until the return temperature reaches $50-60 \mathrm{~K}$. In the third phase of warmup, the return flow into the quencts header is shut off, and the CCWP takes over and warms the magnet to room temperature. The clean warm gas is supplied through the warm header and the cold gas returns to the CCWP module through the return heider. The cooling capacity of the return gas is recovered through the CCWP heat exchanger. The nominal flow rate for warmup of one magnet is approximately $50 \mathrm{~g} / \mathrm{s}$. This flow rate depends upon other activities of the CCWP module.

\section{OPERATION OF MULTIPLE TEST STANDS}

The system is presently configured with five distribution boxes that are connected to two common headers containing multiple supply and return lines. The refrigeration recovery system is designed to 


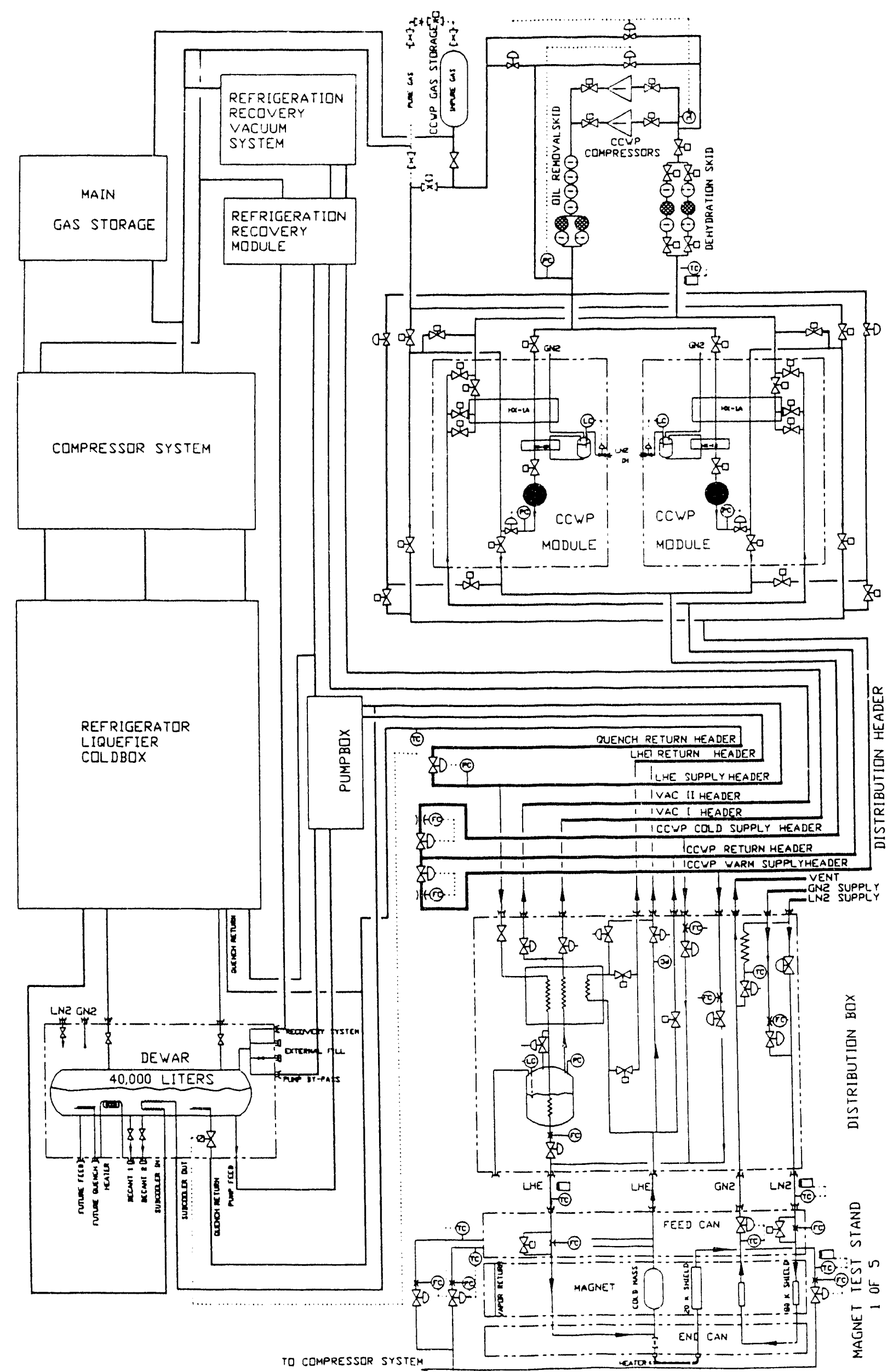

FIGURE 3. CCWP AND DISTRIBUTION SYSTEM 
simultaneously handle three test stands at $3.6 \mathrm{~K}$ with a $100 \mathrm{~g} / \mathrm{s}$ circulation rate and two at $2.5 \mathrm{~K}$ with a $50 \mathrm{~g} / \mathrm{s}$ circulation rate. The pump box circulation pumps can provide flow rate in excess of $500 \mathrm{~g} / \mathrm{s}$ and, along with direct makeup supply from the refrigerator, more than five magnets can be tested at a given time. Various combinations of cleaning, cooling, and warmup functions can be performed on multiple stands up to the CCWP system's capacity of $110 \mathrm{~g} / \mathrm{s}$. All the CCWP activities can be executed in parallel on some stands while cold tests are being carried out on other stands. The quench header experiences varying operating conditions depending on whether quenches and cooldowns happen simultaneously or independently. The controls and operation of the quench/cooldown header with multiple test stands will be discussed in a following section. Table 2 shows the static and minimum pump work and Table 3 shows the test stand loads. Table 4 shows the corresponding load on the refrigerator/liquefier. From these tables, one can determine the various possible test stand operating cornbinations that the system capacity will allow. The system's inventory and energy management philosophy allows transients such as quenches, cooldowns, and quench recoveries to be treated as average loads.

\section{OTHER OPERATIONAL CONFIGURATIONS}

The system can be operated without the pump box makeup pump by supplying the makeup flow directly from the refrigerator via the dewar subcooler into the liquid helium supply header (Figure 2). The system can also be operated without either circulation or makeup pumps by supplying all the flow directly from the refrigerator at $4 \mathrm{bar}(180 \mathrm{~g} / \mathrm{s})$ via the dewar subcooler to the supply header. In this case the flow will return to the dewar via the quench return header. The flow can also be roturned to the dewar via the pump bypass if the pump box remains cold, allowing the quench return header to be used for cooldown, warmup, and quenches. The circulating flow is limited to the supply available from the refrigerator. When the system is operated without pumps, the bypass valve between the supply and quench return header will be used for transient operating conditions to minimize the pressure fluctuation to the refrigerator and to the other test stands.

The system can also be operated without the refrigeration recovery unit. A subcooler bath temperature of $4.3 \mathrm{~K}$ can be achieved since the vapor return lines from the distribution boxes and pump box are connected to the low pressure side of the refrigerator. If the refrigeration recovery module connection to the low pressure side of the main refrigerator is available, then the subcooler in the distribution box can be used; otherwise, the low temperature is limited to the dewar conditions or pump box subcooler conditions.

\section{QUENCH MANAGEMENT}

A pressure rise in the magnet loop or a quench signal initiates a quench sequence for the cryogenic system. This involves the opening of the quench return valve and the closing of the liquid helium supply and return valves in the distribution box, and the opening of the isolation valve between the quench header and the dewar. The dewar valve will remain open for minimum preset time (e.g., 30 seconds) before the temperature controller is allowed to take over. Sudden closing of the distribution box supply valve will cause the pressure to build up in the supply header and will activate the circulation pump bypass or the pressure control valve between the supply header and quench header. When the temperature of the flow in the quench header exceeds $12 \mathrm{~K}$, the isolation valve to the dewar is closed. The flow then goes to the coldbox, where it is admitted to the appropriate heat exchanger. Because the isolation valve to the dewar remains open for a brief preset period before the temperature controller takes over, cooldown gas from another magnet stand may also be admitted to the dewar. The pressure control valve on the coldbox cooldown/quench return line maintains the quench header pressure at 2.1 bar, which is above the dewar maximum operating pressure. The cooldown/quench line in the coldbox and the compressor suction line have independent vents to prevent the compressor suction pressure from rising above the maximum limit. The bypasses and the surge vessels in the pump box will also smooth out the transients caused by the quench sequence.

Table 2. Static heat load and minimum pump work

\begin{tabular}{|l|c|}
\hline \multicolumn{2}{|c|}{ Static heat leak } \\
\hline Pump box heat leak & $80 \mathrm{~W}$ \\
\hline Transfer lines heat leak & $163 \mathrm{~W}$ \\
\hline Dewar heat leak & $7 \mathrm{~W}$ \\
\hline Refrigeration recovery & $30 \mathrm{~W}$ \\
\hline Total & $280 \mathrm{~W}$ \\
\hline & \\
\hline
\end{tabular}

\begin{tabular}{|l|c|}
\hline \multicolumn{2}{|c|}{$\begin{array}{c}\text { Minimum pump work } \\
\text { (idle \& bypass control) }\end{array}$} \\
\hline Circulation pump (Idle 10\%) & $20 \mathrm{~W}$ \\
\hline Make-up pump (Idle 10\%) & $90 \mathrm{~W}$ \\
\hline Total Idle & $110 \mathrm{~W}$ \\
\hline Circulation pump (Bypass 2\%) & $4 \mathrm{~W}$ \\
\hline Make-up pump (Bypass 2\%) & $18 \mathrm{~W}$ \\
\hline Total bypass & $22 \mathrm{~W}$ \\
\hline
\end{tabular}


Table 3. Test stand loads

\begin{tabular}{|l|c|c|c|}
\hline \multicolumn{1}{r|}{ Test stand at: } & $\mathbf{4 . 4} \mathbf{K}$ & $\mathbf{3 . 6 \mathrm { K }}$ & $\mathbf{2 . 5} \mathbf{K}$ \\
\hline Circulation + make-up flows & $100 \mathrm{~g} / \mathrm{s}+3 \mathrm{~g} / \mathrm{s}$ & $100 \mathrm{~g} / \mathrm{s}+8.8 \mathrm{~g} / \mathrm{s}$ & $50 \mathrm{~g} / \mathrm{s}+7.3 \mathrm{~g} / \mathrm{s}$ \\
\hline Pump work & $86 \mathrm{~W}$ & $110 \mathrm{~W}$ & $70 \mathrm{~W}$ \\
\hline Discribution box leak & $39 \mathrm{~W}$ & $39 \mathrm{~W}$ & $39 \mathrm{~W}$ \\
\hline Test stand heat load & $51 \mathrm{~W}$ & $51 \mathrm{~W}$ & $51 \mathrm{~W}$ \\
\hline Lead cooling & $1 \mathrm{~g} / \mathrm{s}$ & $1 \mathrm{~g} / \mathrm{s}$ & $1 \mathrm{~g} / \mathrm{s}$ \\
\hline Refrigeration Recovery & $0 \mathrm{~g} / \mathrm{s}+0 \mathrm{~W}$ & $1.5 \mathrm{~g} / \mathrm{s}+50 \mathrm{~W}$ & $1.5 \mathrm{~g} / \mathrm{s}+$ \\
\hline Total /stand & $176 \mathrm{~W}+1 \mathrm{~g} / \mathrm{s}$ & $250 \mathrm{~W}+2.5 \mathrm{~g} / \mathrm{s}$ & $200 \mathrm{~W}+2.5 \mathrm{~g} / \mathrm{s}$ \\
\hline \# of stands & $\mathrm{N} 1$ & $\mathrm{~N} 2$ & $\mathrm{~N} 3$ \\
\hline
\end{tabular}

Table 4. Estimation of average load on the refrigerator/liquefier

\begin{tabular}{|l|c|c|}
\hline Total for stands @4.5K & $\mathrm{N} 1 \times(176 \mathrm{~W}+1.0 \mathrm{~g} / \mathrm{s})$ & $\mathrm{Q} 1$ \\
\hline Total for stands @3.6K & $\mathrm{N} 2 \times(250 \mathrm{~W}+2.5 \mathrm{~g} / \mathrm{s})$ & $\mathrm{Q} 2$ \\
\hline Total for stands @2.5K & $\mathrm{N} 3 \times(200 \mathrm{~W}+2.5 \mathrm{~g} / \mathrm{s})$ & $\mathrm{Q} 3$ \\
\hline Total static heat leak & $280 \mathrm{~W}$ & $\mathrm{Q} 4$ \\
\hline Pump bypass load & $22 \mathrm{~W}$ & $\mathrm{Q} 5$ \\
\hline $\begin{array}{l}\text { Average quench load } \\
\text { N4 \# of quenches/8 hrs* }\end{array}$ & $\mathrm{N} 4 \times 17 \mathrm{~W}$ & $\mathrm{Q} 6$ \\
\hline $\begin{array}{l}\text { Average quench recool/recovery } \\
\text { N5 \# of recools/8 hrs** }\end{array}$ & $\mathrm{N} 5 \times 0.35 \mathrm{~g} / \mathrm{s}$ & $\mathrm{Q} 7$ \\
\hline $\begin{array}{l}\text { Average cooldown load }(80-4.5 \mathrm{~K}) \\
\text { N6\# of cooldowns/week }\end{array}$ & $\mathrm{N} 6 \times 0.18 \mathrm{~g} / \mathrm{s}$ & $\mathrm{Q} 8$ \\
\hline Average leakage losses & $0.5 \mathrm{~g} / \mathrm{s}$ & $\mathrm{Q} 9$ \\
\hline Total load *** & $\mathrm{Q} 1+\ldots+\mathrm{Q} 9$ & $\mathrm{Q}_{\mathrm{T}}$ \\
\hline System capacity & $2100 \mathrm{~W}+21 \mathrm{~g} / \mathrm{s}$ & $\mathrm{Q}_{\mathrm{A}}$ \\
\hline
\end{tabular}

* Based on $0.5 \mathrm{MJ} /$ quench.

* Based on $1.0 \mathrm{MJ} /$ quench

** $1 \mathrm{~g} / \mathrm{s}$ of liquefaction capacity $\approx 100 \mathrm{~W}$ of refrigeration capacity at $4 \mathrm{~K}$

$N 1$, N2...N6 are selected so that $Q_{T}$ stays within system capacity $\left(Q_{A}\right)$.

\section{LHE DEWAR QUENCH MANAGEMENT AND ENERGY CAPACITY}

The 40,000 liter liquid helium dewar serves as a liquid inventory and quench energy manager for the refrigerator/liquefier.

The dewar serves as an energy buffer between the refrigerator/liquefier and the magnet quenches. Approximately half a megajoule is expected to be released into the return helium during a single magnet quench. The magnet test stand contains approximately $20 \mathrm{~kg}$ of helium inventory and the average enthalpy increases by $25 \mathrm{j} / \mathrm{g}$, which is returned to the dewar. In order to absorb the energy, dewar vapor pressure is allowed to rise to 2.0 bar. A maximum operating dewar pressure of 2 bar is selected to prevent the dewar pressure from reaching the supercritical state. Figure 4 shows the mass that can be added to the dewar when the dewar pressure is limited to 2 bar (or to fill the dewar) as a function of initial dewar liquid volume fraction for various average enthalpy levels of the quench mass flow. For high initial dewar levels, and low enough enthalpy levels of the quench flow, the dewar will fill before 2 bar is reached. Points on the downward trend of these curves correspond to a full dewar. At an initial liquid level of approximately 50 percent volume, the mass absorbed in the dewar at an enthalpy level of $35 \mathrm{j} / \mathrm{g}$ is about $400 \mathrm{~kg}$, corresponding to a total energy addition of $14 \mathrm{MJ}$.

The dewar also serves as a buffer during phase three of cooldown. The flow rate and energy level for this condition is very small and would be a small transient for the dewar. A higher amount of energy may be added to the dewar if a quench should occur during the second cooldown phase of another magnet. In this situation, the warmer gas is also admitted into the dewar until the temperature controller takes over and the valve to the dewar is closed. The additional amount of energy that can be dumped into the dewar, assuming the cooldown gas in the quench header is at $430 \mathrm{j} / \mathrm{g}$. can be as high as $1 \mathrm{MJ}$. The dewar should be able to absorb over 15 single magnet quenches in a short duration and still maintain a satisfactory operating pressure. 


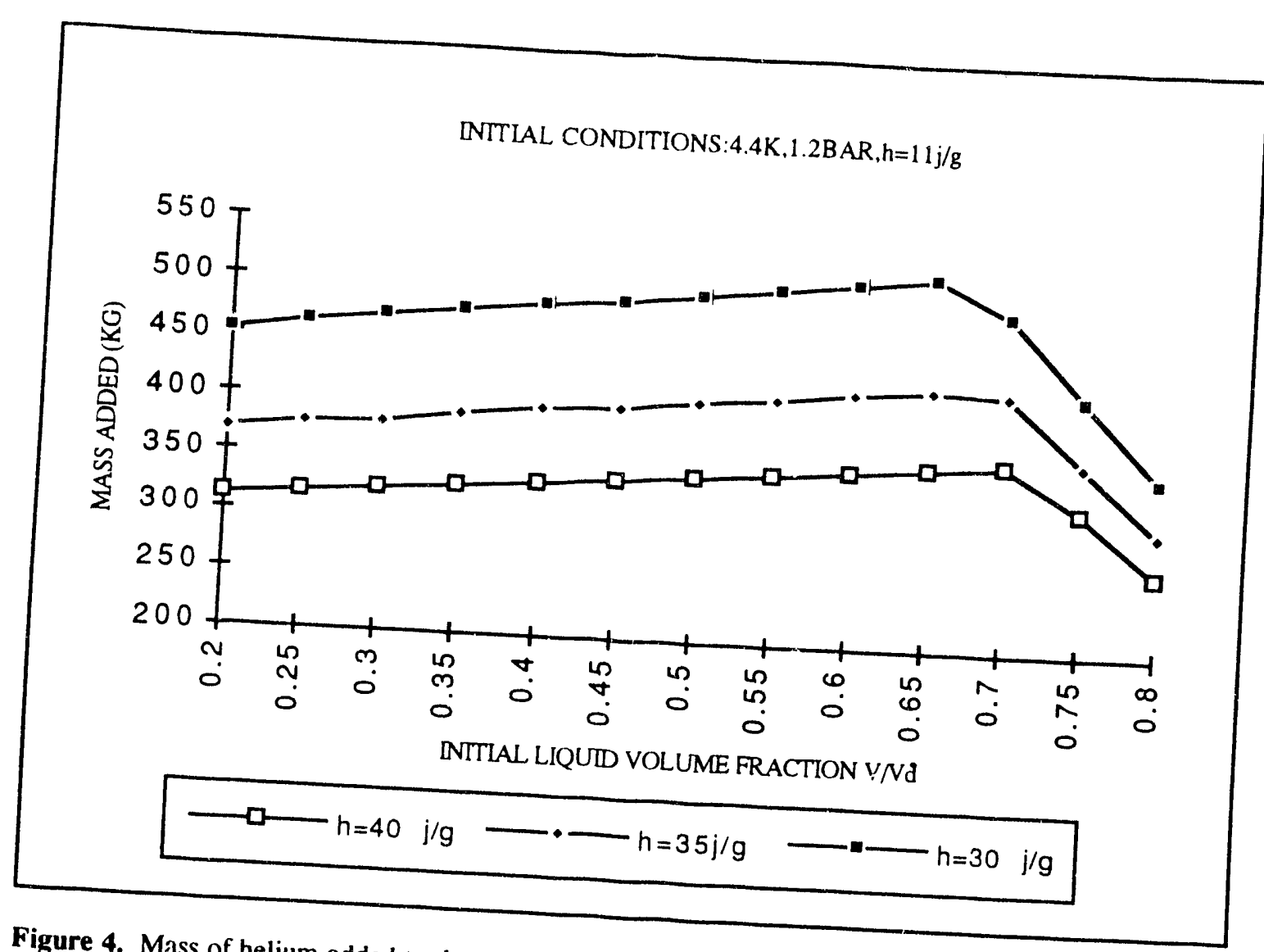

Figure 4. Mass of helium added to dewar vs. initial liquid volume (for three average enthalpies of the
quench flow to dewar to reach 2 bar or to fill the dewar)

\section{INVENTORY MANAGEMENT}

The total MTL cryogenic system has two helium compressor systems. The gas inventory varies the CCWP system varies depending on the cooldown operation of the multiple test stands. The inventory ir: The net inventory transfer between the main refrigeratorliquefier of the magnet test stands with this unit. the condition at which the transfer of the cooldown excess inventory in the CCWP system is purified and stored in function occurs between these systems. The system compressors or to the refrigeration recovery system. system storage may be supplied to the CCWP gas storery system. Helium gas from the main refrigeration

\section{SUMMARY}

conditions of $100 \mathrm{~g} / \mathrm{s}$ and $4 \mathrm{~K}$. Magnets can be conditioned six cold magnet tests at collider operating average installed compressor power for each operating cold at temperatures between $4.5 \mathrm{~K}$ and $2.5 \mathrm{~K}$. The vacuum pumps it is $305 \mathrm{~kW}(410 \mathrm{HP})$. This overview has presented is $270 \mathrm{~kW}$ (360 HP); including the accompanying of the Magnet Test Laboratory cryogenic system. The various operating modes, features, schedule efficiency. The philosophy allow the test facility to be operated with of the system and the The cryogenic system for the Accelerator Syst

\section{REFERENCES}

1 Udo Wagne Supercollider 3. Proceedings of the Third International Industrial Symposium on MTL cryogenic system,"
Plenum Press. 

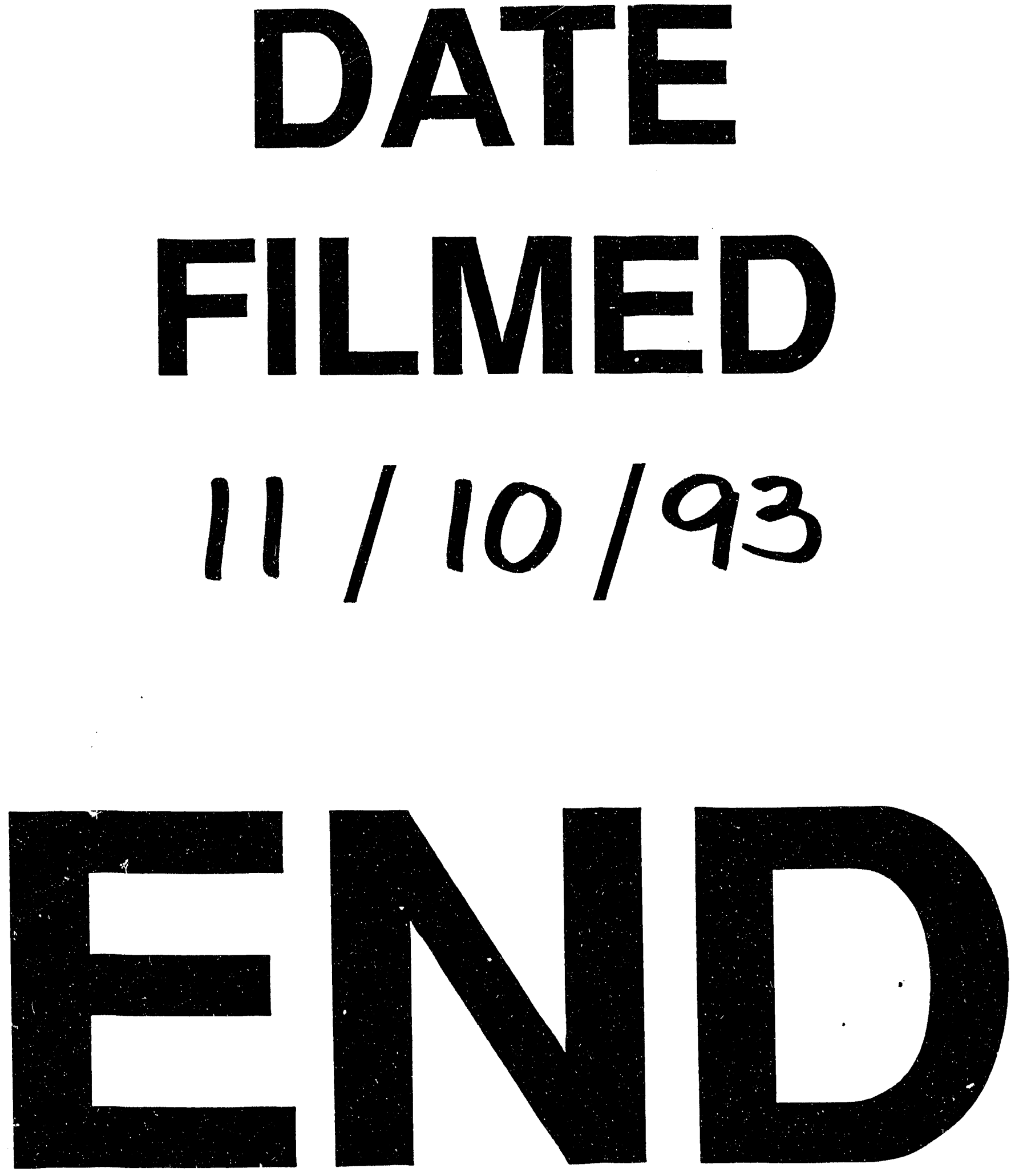